\title{
A construção do poder em Angola nos romances de Pepetela: os novos ricos e a apropriação do Estado no pós-independência
}

\author{
The Construction of Power in Angola in \\ Pepetela's Novels: the New Rich and the Appropriation \\ of the State in the Post-Independence Period
}

Carolina Bezerra Machado*,**

\section{Resumo}

No artigo, analiso as relações de poder construídas entre o Estado e a sociedade em Angola após a independência do país em 1975, a partir de suas ambivalências e acomodações de interesses. Defendo que houve a construção de uma estrutura política em que o Estado/ MPLA passou a ser o principal meio para a distribuição de benefícios e privilégios, contribuindo para o fortalecimento de uma estrutura autoritária e patrimonialista ao longo dos anos. Ao destacarem um cenário de autoritarismo, clientelismo e patrimonialismo, os romances de Pepetela e a construção de seus personagens dialogam com uma narrativa crítica acerca do projeto político adotado pelo Estado angolano.

Palavras-chave: Angola; Pepetela; Estado e sociedade

\section{Abstract}

In the article I analyze the power relations built between the State and society in Angola after the country's independence in 1975, based on its ambivalences and accommodation of interests. I argue that there was the construction of a political structure in which the State/ MPLA became the main means for the distribution of benefits and privileges, contributing to the strengthening of an authoritarian and patrimonialist political structure over the years. By highlighting a scenario of authoritarianism, clientelism and patrimonialism, Pepetela's novels and the construction of his characters dialogue with a critical narrative about the political project adopted by the Angolan State.

Keywords: Angola; Pepetela; State and society

\footnotetext{
* Universidade Federal do Estado do Rio de Janeiro (UNIRIO), Rio de Janeiro, RJ, Brasil. lowbezerra@ gmail.com <https://orcid.org/0000-0002-2751-0786>

** Esta pesquisa conta com financiamento da Coordenação de Aperfeiçoamento de Pessoal de Nível Superior (CAPES).
} 
Realmente, no fim dos anos 1980, princípios dos anos 90, surge essa classe, nova classe, que é uma burguesia. Uma burguesia não produtiva, burguesia de consumo de luxo, particularmente luxo, que se vai chamar talvez de um grupo ou uma seita de novos ricos. ${ }^{1}$

A passagem acima, retirada de uma entrevista concedida pelo escritor angolano Pepetela, retoma um tema fundamental presente em muitos de seus romances: a construção de um grupo social em Angola, pautado por novos valores que tencionam a política no país após a independência. Seus personagens retratam as diferentes formas de autoritarismo presentes na sociedade. Em diversos momentos, nos são representadas as submissões interpostas entre o Estado e os indivíduos. Essa perspectiva apresentada nos romances dialoga com uma historiografia recente, ainda que muitas de suas reflexões só tenham sido mais aprofundadas e debatidas pelas ciências sociais posteriormente.

Se logo após a independência havia a defesa da criação de uma sociedade mais justa, igualitária e democrática, aos poucos a política passava a ser vista como sinônimo de propriedade daqueles que a controlavam (Santos, 1995). As mudanças ocorridas no regime de Estado angolano "fracassaram em produzir uma transformação sistêmica que reforçasse a institucionalização" (Chabal, 2009 [2008], p. 28), da mesma forma que não possibilitaram um desenvolvimento democrático que pudesse dar espaço para o reconhecimento da sociedade civil. Esta sempre esteve atrelada às benesses do Estado, em torno de um modelo clientelista que deriva do regime patrimonialista, em que "os governantes controlam os recursos do país e deles dispõem de forma a garantir a legitimidade e o apoio necessário para permanecerem no poder" (Chabal, 2009).

Conforme salienta Nuno Vidal, Angola ainda permanece sobre restrições no que diz respeito aos direitos civis e políticos. Para o intelectual, "a estrutura política [de Angola] serve à lógica patrimonial clientelista, independentemente do modelo político formal existente (socialista, monopartidário ou capitalista multipartidário)" (Vidal, 2006, p. 12). Ao longo dos anos, se estruturou um sistema institucional de privilégios sociais em que o partido passou a ser a principal ligação para a distribuição de benefícios e bens materiais. Protagonizou-se uma grande centralização política e administrativa que tinha na figura do presidente o grande líder.

Através do destaque que a política clientelista e neopatrimonialista ganhou durante o governo de José Eduardo dos Santos, somos envolvidos pelas intensas relações de poder que se desenvolveram entre o Estado e a sociedade 
civil. Nesse sentido, a partir da Fundação Eduardo dos Santos (FESA), compreendemos como se dá a relação desta com a sociedade. A Fundação, com dinheiro provindo "de doações implicitamente obrigatórias provenientes do setor privado e da Sonangol" ${ }^{2}$, fornece ajudas e ofertas em nome do presidente, traduzindo a falta de limites entre o público e o privado em Angola (Oliveira, 2015, p. 81).

Além disso, por mais que a revisão constitucional de 1991 tenha permitido a emergência de partidos políticos e a criação de organizações da sociedade civil, os primeiros ainda enfrentavam um espaço político contraído, enquanto as segundas também sofriam constrangimentos quanto à sua liberdade civil, pois continuava a haver diferentes níveis de intimidação ou violência. Diante disso, é notório que a transição política e econômica que ocorreu na década de 1990, a partir do fim de um Estado socialista, não foi satisfatória, pois o que assistimos foi o Estado se valer de novos meios para manter a sua estrutura política. O aparelho do Estado continuou a ser utilizado para seu próprio benefício, assim como o sistema de cooptação de opositores foi revigorado e aprofundado em um sistema clientelista que "assegurava a manutenção hegemônica do poder" (Vidal, 2016, p. 842).

Nesse sentido, Pepetela representa em seus romances esse aspecto autoritário e patrimonial do Estado, forjado também internamente. A construção de personagens que dialogam entre essas estruturas traz novas reflexões sobre a política do país: a figura-tipo do "novo burguês" abre o leque sobre as estruturas políticas criadas após a independência que permitiram o aparecimento e o fortalecimento desse personagem social de Angola. Nos romances de Pepetela, somos envolvidos por uma série de complexidades que refletem a relação de mão dupla existente entre o MPLA e a sociedade angolana. A partir da acomodação de interesses entre esses núcleos são representados conceitos como clientelismo e patrimonialismo entre os seus personagens, mantendo uma relação ambígua e complexa com o Estado, o que forma as "franjas" do governo. Sendo assim, também cabe problematizarmos a construção de conceitos-chave que podemos retirar das narrativas do escritor: Estado, sociedade civil angolana e corrupção; que ganham, ao longo de seus livros, um grande destaque.

Compreende-se que, ao propor uma reflexão sobre Angola a partir de personagens-tipo, podemos analisar o desenvolvimento de algumas questões importantes para a realidade política do país após a independência. $\mathrm{O}$ escritor aborda o clientelismo, ou seja, a relação vantajosa entre o indivíduo e o Estado, construindo uma troca mútua de interesses que se sobrepõem ao coletivo. 
Essas referências estão diretamente em diálogo com as relações de poder que se estabeleceram em Angola no pós-independência. Por mais que os discursos tenham sido pautados em valores como a democracia e a liberdade, ainda é evidente a permanência de uma cultura política que estrutura um sistema autoritário. Mesmo após as inúmeras mudanças suscitadas pelo Estado, o partido vai adequando os seus comportamentos às transformações, de modo a encontrar um meio de viabilizar e reproduzir os seus interesses políticos (Carvalho Filho, 2012, p. 7).

Parte-se do pressuposto de que o discurso literário é uma forma diferenciada de abordar o real, ao escolher uma dimensão simbólica diferente para dar sentido à experiência vivida (Pesavento, 2006). Construída a partir de uma visão individual, essa experiência passa a ser valorizada, dando margem às subjetividades históricas, que enriquecem o cenário historiográfico. De acordo com a crítica literária Maria Nazareth Fonseca, "o romance pode ser entendido como uma leitura de mundos, ainda que se estruture a partir de estratégias discursivas regidas por princípios próprios à narração inventiva" (Fonseca, 2010, p. 77). Desse modo, devemos interpretar a escrita literária como uma construção da realidade, suscetível, assim como outras formas de se representar o mundo, a disputas e conflitos inerentes à vida do escritor. Pois, a realidade é construída a partir do modo como o contexto social é aprendido, por isso, "as modalidades do agir e do pensar devem ser sempre remetidas para os laços de interdependência que regulam as relações entre os indivíduos" (Chartier, 1990, p. 25).

O que mais importa não é determinar se é ficção ou não, o que entra da esfera da realidade e o que se exclui, mas sim, os testemunhos que escrevem, suas relações com o seu tempo e a sua sociedade. Carlo Ginzburg, em referência a Marc Bloch, nos traz uma importante reflexão metodológica. Para o historiador, "aquilo que o texto nos diz já não constitui o objeto preferido de nossa atenção”, pois não nos interessaríamos mais somente pelos dados concretos das fontes, muitas vezes inventados, mas "pela luz que lançam sobre a mentalidade de quem escreveu esses textos". Teríamos, assim, "nos emancipado daquela subordinação ao passado", pois conseguimos ir além do que as fontes nos descrevem, "embora ainda fiquemos presos em seus rastros". Assim sendo, caminhar pelos terrenos da ficção para fazer emergir os "testemunhos involuntários", "as vozes incontroladas" que se encontram nos textos, é de extremo interesse para o trabalho (Ginzburg, 2007, p. 10).

A partir destas considerações, o romance é visto como um lugar de tensão, em que as disputas ideológicas, o clima de uma época, assim como as repre- 
sentações sociais são tecidas e encenadas a partir de escolhas discursivas que, por uma dimensão simbólica, são sensíveis às demandas de uma geração, influenciando o modo como enxergamos o mundo. $\mathrm{O}$ texto literário não é visto apenas como reflexo de uma realidade, pois ele contribui para a sua construção a partir de novas leituras de mundo. Ao considerarmos que o real é "construído, visto e sentido de diferentes formas", a literatura ganha novos significados. Como afirma Pesavento, "por vezes, a coerência de sentido que o texto literário apresenta é o suporte necessário para que o olhar do historiador se oriente para outras tantas fontes e nelas consiga enxergar aquilo que ainda não viu" (Pesavento, 2006, p. 22).

\section{Poder e Autoritarismo em Desejo de Kianda e Predadores}

Ao nos voltarmos para as construções literárias de Pepetela, mais precisamente para dois personagens centrais de seus livros, Carmina Cara de $\mathrm{Cu}$ (Desejo de Kianda) e Vladimir Caposso (Predadores), somos envolvidos nas metamorfoses que o MPLA vivenciou ao longo dos anos. Podemos destacar como, de diferentes formas, esses indivíduos se apropriaram do Estado em benefício próprio, elevando o grau de neopatrimonialismo e nepotismo existente na estrutura política angolana. Desse modo, o artigo volta-se para a construção desses personagens, no intuito de compreendermos como a política angolana é ressignificada e apropriada dentro de uma lógica de poder autoritária e patrimonial que faz parte da ordem política remanescente em Angola mesmo após a transição política para o multipartidarismo.

A partir desses personagens nos deparamos com a representação de uma estrutura política que, se a princípio parece frágil, mantém a sua firmeza e habilidade justamente a partir dos favorecimentos praticados pelo Estado a grupos sociais privilegiados no país. Levando em consideração essa afirmação, podemos encontrar nesses romances diversos exemplos de como, aos poucos, se consolidou um determinado modelo político que não tinha por objetivo ampliar direitos ou mesmo solidificar uma democracia que parecia instável. Ao contrário, encontramos, em sua narrativa, os meios utilizados por determinados grupos políticos para permanecerem no poder, se apropriando de discursos e debates políticos visando a conquistar este objetivo. Um dos exemplos mais marcantes dessas práticas, que já acompanhava o partido desde os primeiros tempos da independência, foi o jargão socialista, o qual, para alguns políticos mais próximos, apenas teria sido utilizado como estratégia para a obtenção de vantagens pessoais. Ou mesmo "o vocabulário marxista-leninista”, 
apenas aplicado como retórica para o alcance de favorecimentos (Bittencourt, 2010, p. 142).

Devemos considerar que essa posição também se relaciona com a desilusão de um projeto socialista democrático, defendido por membros do MPLA e que nunca chegou a se concretizar. Desse modo, essa crítica aparece claramente nos romances do escritor Pepetela. Em Desejo de Kianda, Carmina desde muito cedo já era descrita como uma menina que gostava das "artes do mando" (Pepetela, 2008a, p. 6), por isso, não parecia haver para si outra saída que não fosse a política. Nesse sentido, as relações de poder no romance mantêm-se afastadas dos valores democráticos à medida que são caracterizadas como práticas de alguns, geralmente daqueles que têm uma vertente autoritária, como são descritos os personagens de Pepetela. Além disso, aqueles que aparecem próximos do governo no pós-independência são representados como homens corruptos, ignorantes e oportunistas. Enquanto, ao mesmo tempo, o MPLA repeliu os homens bons. Estes, se no início simpatizavam com o movimento, muitas vezes fazendo parte de seu quadro de militantes, com o tempo acabaram sucumbindo. Cria-se uma ordem política individualista e clientelista que rompe com o projeto revolucionário de outrora.

A postura pedante de Carmina ainda menina em seu bairro não agradava os vizinhos e, por isso, ela recebera o apelido de CCC (Carmina Cara de Cu). Rapidamente a jovem ingressou na Jota (Juventude partidária do MPLA) e, de lá, conseguiu conquistar cargos mais importantes dentro do partido, destacando-se no aparelho burocrático. Aos dezoito anos, já era responsável por um setor. É a partir da sua trajetória política, que se mistura em vários níveis com a sua vida pessoal, que Carmina passa a ser a representação da estrutura política que se desenvolve após a independência. Por outro lado, João Evangelista, marido de Carmina, aparece como contraponto desse personagem que carrega o autoritarismo em sua essência. Aos poucos, ele vai se transformando em objeto dessa relação - o que, inclusive, o leva a um processo de desumanização, conforme veremos. Junto a estas questões, um fenômeno curioso cerca a história: a queda de prédios e o canto de Kianda, episódios nos quais, mais uma vez, Pepetela recorre ao imaginário, aos signos e às tradições angolanos para resistir ao processo de degradação humana implementado pelas novas relações políticas e econômicas. Todavia, por mais que Evangelista se afastasse das concepções preconceituosas e autoritárias da mulher, se deixava levar pelos privilégios que conseguia alcançar ao lado dela.

Já em Predadores, somos envolvidos por uma narrativa que aborda o engrandecimento político e social de Vladimir Caposso, de homem simples, pobre 
e sem posses a grande empresário. A ascensão de uma classe burguesa em Angola é protagonizada por esse personagem. ${ }^{3}$ A grande virada ocorre com a sua entrada para o MPLA, a partir das oportunidades que a vida lhe concede. ${ }^{4} \mathrm{Ca}$ posso consegue se filiar ao movimento, o que lhe traz facilidades e privilégios que o levam à conquista de poder e riquezas: "Caposso... puxou de toda a lábia para mostrar empenho, desde quase criança, em fazer parte do glorioso movimento [...]" (Pepetela, 2008b, p. 184). Mas o funcionário do partido lhe diz:

Sem testemunhas é muito difícil ser admitido, compreende, há muita gente que era da PIDE $^{5}$ ou dos movimentos inimigos e querem entrar na organização para sabotar pelo interior, nós temos de evitar as infiltrações, mas cochichando a seguir, claro que algumas notas tapam os buracos e evitam as infiltrações e ele suando perguntou quanto era preciso para tapar os vazamentos, tendo obtido resposta satisfatória, tinha o suficiente no bolso (Pepetela, 2008b, p. 184).

Vladimiro Caposso nunca foi dado à política. O seu interesse por ela estava diretamente condicionado às benesses que ela poderia lhe trazer. A partir da sua filiação em 1975 nasce um novo homem, ligado às tradições nacionalistas e socialistas. O personagem forja no próprio nome a homenagem ao líder revolucionário russo, Lênin, mas também o principal lema do partido, "A vitória é certa". Diante disso, sua assinatura passa a ser VC. Da mesma forma que utilizou o novo nome para se aproximar dos ideais do movimento, outras tradições também foram inventadas: a família revolucionária anticolonial, o local de nascimento - Catete, de modo a se aproximar do presidente Agostinho Neto -, a ideologia socialista e o seu prazer pela política.

É interessante notarmos o destaque que Pepetela dá, ao longo do romance, às facilidades que Caposso teve por ter forjado um novo nome, assim como uma nova região de origem. Tal ênfase está diretamente ligada aos "vínculos de solidariedades" criados internamente no MPLA, dentre eles, o regionalista. Como aponta Marcelo Bittencourt, havia diversos confrontos políticos no interior do movimento e, muitas vezes, as "disputas por espaço ou por pequenas vantagens no MPLA passavam por estas associações”. E continua: "É assim que se adquire consistência a acusação de que existia um grupo formado por indivíduos do Catete (...) era um dado que poderia, sem dúvida, ser útil a esses militantes nas intrincadas disputas no interior do movimento" (Pinto, 2002, p. 582).

A estória do livro se desenrola entre 1974 e 2004. Em 1975, o ano da independência, Caposso já estava, havia alguns meses, em Luanda, e, aos poucos, se inteirava dos assuntos políticos, sem grande entusiasmo, através de seu ami- 
go Sebastião Lopes. Os primeiros anos do pós-independência são narrados a partir das incertezas que rondavam o período. O medo da guerra e a desconfiança com o movimento do MPLA foram revividos nas páginas de Predadores, a partir de um olhar particular, de um homem que já havia passado pelas desilusões que o levaram a retirar-se do MPLA na década de $1980 .{ }^{6}$

Ao nos voltarmos para CCC e para Caposso, bem como para o modo com que o poder é desenvolvido por esses personagens, podemos perceber o quanto suas práticas autoritárias vão além dos limites do Estado e invadem a vida privada das pessoas que estão próximas. As relações de medo que são narradas nas páginas de Predadores são marcantes e refletem o contexto político que vivia Angola. Assim, o assassinato da amante de Caposso deve ser recapitulado:

Caposso apontou com frieza do lado de fora do quarto, retendo a respiração, como aprendera da arte de bem disparar. Esvaziou o carregador da pistola. Os tiros foram bastante abafados pelo barulho atroador da carreata. Entrou no quarto, empurrou com o cano da pistola o corpo do homem morto. Verificou que ela também estava morta, três buracos perto do coração. Nem souberam porquê morreram, foi pena, a cabra devia sofrer com o medo da morte, para perceber o que lhe acontecia, e perceber também os riscos incorridos ao gozar com ele (Pepetela, 2008b, p. 16).

Essa estória aparece como a primeira narrativa do livro que se inicia em setembro de 1992. Em meio a um cenário político de incertezas e irrequieto com os rumos que o país poderia tomar, Caposso, a essa época já um grande empresário, assassina a sua amante quando descobre que esta estava lhe traindo com um outro homem. Assim morrem os dois. É importante ainda ressaltar que esse assassinato não foi retomado no livro, ou seja, a impressão que o escritor transmite é a de que tudo teria ficado por isso mesmo, sem julgamentos. Não teria ocorrido investigação a sério, ainda mais com o bilhete que Caposso teria deixado meticulosamente sobre os corpos: "Ninguém trai a UNI$\mathrm{TA}^{7}$ sem deixar a vida" (Pepetela, 2008b, p. 17), transferindo a motivação pessoal para um ato político em plena disputa eleitoral após a abertura para o multipartidarismo.

Ao relembrarmos que Predadores se inicia em 1992, o cenário descrito por Pepetela aponta para uma disputa política eleitoral entre a UNITA e o MPLA, os principais partidos que concorriam às primeiras eleições multipartidárias desde a independência. Todavia, notamos claramente a privatização 
do setor público à medida que o narrador descreve que, enquanto Caposso tentava entrar no apartamento para cometer o assassinato, evitando fazer barulho, do lado de fora aconteciam as carreatas de campanha eleitoral, que pertenciam ao "patrimônio do Estado" e traziam agitações de "bandeiras rubro-negras, cartazes, jovens de camisolas vermelhas e punhos erguidos, gritando slogans e canções políticas" (Pepetela, 2008b, p. 15). Esse cenário chama a atenção novamente para a mistura de símbolos e signos que cercam o Estado e o partido, que propositalmente confundem-se por terem as mesmas cores e partilharem de bandeiras parecidas, em uma clara dominação do Estado pelo partido (Oliveira, 2015).

Podemos considerar, ainda, as relações estabelecidas entre o empresário e seus funcionários, descritos como se fossem propriedades suas ${ }^{8}$, ou mesmo os desmandos em casa - com sua mulher Bebiana e seus filhos - como exemplos de práticas sociais autoritárias que também se articulam com a estrutura política de Angola após a independência. ${ }^{9}$ Pepetela constrói uma narrativa que aponta para a persistência de uma cultura política a qual se reproduz e se renova, criando diferentes formas de se articular com as mudanças políticas e sociais ocorridas. Assim, a falta de desenvolvimento de um Estado democrático é proposital e assegura o poder restrito a poucos, do mesmo modo, a falta de investimentos sociais continua reproduzindo relações baseadas no autoritarismo.

Nesse sentido, Messiant, ao se debruçar sobre as formas de governação do Estado angolano que contribuíram para a transição para o multipartidarismo, reflete como essa mudança não foi acompanhada de uma transição para a democracia. As relações políticas continuaram restritas e sendo construídas a partir de interesses particulares, mantendo um sistema de dominação hegemônico desigual, com caráter predatório, em diálogo com o modelo político clientelista (Messiant, 2006, p. 133). Caposso passa a ser a representação do modo como parcelas da sociedade angolana se articulam com o Estado em diferentes níveis, apontando para o alastramento da corrupção e da prática clientelista, bases para o desenvolvimento informal do sistema político angolano.

Ao ampliarmos esse quadro, podemos fazer um paralelo com as relações de poder que foram desenvolvidas entre o MPLA e a sociedade. Afinal, se, por um lado, o desenvolvimento do poder do Estado não pode deixar de levar em consideração o peso das interferências internacionais, por outro também devemos estar atentos à sua política interior e ao "monopólio efetivo da violência legítima” (Messiant, 2006, p. 137). Os tempos de um regime monopartidarista, em que figurava uma política de medo e autoritária, tiveram o seu ápice após o 
movimento nitista, em 1977. Contudo, mesmo após o processo de transição para o multipartidarismo, o que assistimos foi o "desenvolvimento da predação e da coerção", assim como de "um Estado militaro-policial” (Messiant, 2006, p. 140). Em um novo cenário de guerra, em que temos a remilitarização do regime, quem não está com o MPLA é considerado um inimigo e um aliado da UNITA. Esse cenário político bipolarizado é reforçado pelo partido.

Nesse sentido, cabe destacar que, se em Desejo de Kianda as relações políticas ainda aparecem muito bipolarizadas, caracterizando o pouco avanço de um sistema político multipartidário, em Predadores, escrito em 2005, o cenário já abre espaço para as organizações de sociedade civil que passam a se destacar após o fim da guerra, ocorrido em 2002. Todavia, ainda em 1995, novamente em Desejo de Kianda, frente ao desalento com a retomada da guerra civil, Pepetela apresenta reflexões sobre o âmbito político em Angola. Para além de uma estrutura política partidária, o escritor abre espaço para uma luta de classes utópica entre os vestidos e os nus, ao problematizar a pobreza que cercava os homens na capital angolana, que entre os destroços dos prédios caídos andavam sem roupas pedindo esmolas:

Nós não queremos ser um partido. Queremos dinamizar um movimento de revolta que obrigue o Estado a ignorar as ordens do FMI (Fundo Monetário Internacional), que estão a empobrecer cada vez mais os cidadãos para benefício dos estrangeiros e de alguns corruptos. Por isso esse movimento tem de partir da iniciativa das pessoas. Elas não podem ser espartilhadas por partidos que perseguem os seus objetivos próprios de poder. Aliás, já somos muitos a pensar que isso de partidos talvez esteja bem para a Europa, foi lá onde foram inventados, mas que aqui precisamos de outras formas mais nossas de organização. Temos de ousar pensar com as nossas cabeças (Pepetela, 2008a, p. 113).

O movimento lutava a favor da "igualdade social" à medida que buscava arrancar as roupas dos ricos (Pepetela, 2008a, p. 113). As decisões seriam tomadas a partir de um caráter democrático com reuniões abertas a todos que se interessassem, em uma crítica ao modelo limitado e autocrático dos partidos. Essa posição política que nega o modelo partidarista e político a partir de um viés europeu é uma marca da leitura sobre as relações políticas do escritor angolano. Por vezes em entrevistas, Pepetela buscou afirmar o seu desejo de estabelecer uma nova ordem política em Angola, que não estivesse condicionada ao modelo colonial europeu. Desse modo, cabe retomarmos um trecho de uma entrevista concedida pelo autor: "Acho que os africanos têm de pensar 
que é possível e necessário inventar modelos políticos e socioeconómicos que contemplem valores positivos das tradições. Talvez seja tarde demais, mas valia à pena tentar" (Pepetela, 2019, p. 257-259). A partir dessa afirmação, o escritor aponta para a valorização da cultura angolana, principalmente a partir da retomada de signos e valores que podem ser observados com o desenvolvimento de uma narrativa que traz a Kianda dos contos angolanos como uma importante figura simbólica para a resolução dos conflitos ocorridos no país.

Essa posição política, que aparece de modo restrito no final de Desejo de Kianda, mas demonstra uma insatisfação política com os rumos do Estado angolano, também tem espaço em Predadores. Após a vitória do MPLA na guerra, com o surgimento das organizações civis, é demarcado um novo momento político. A criação da DECTRA, uma associação em defesa dos criadores tradicionais, representa uma nova forma de se fazer política. E é a partir dela que Caposso enfrenta as suas primeiras derrotas no campo político e jurídico, que o conduzirão à falência. Conforme ressalta Bittencourt, a mobilização política em torno dessas organizações, após o cenário de guerra, traz novas reflexões sobre o político, que é extrapolado "para outras esferas que não apenas a dos partidos, e esse novo cenário era estranho e parecia escapar ao controle do MPLA" (Bittencourt, 2015, p. 251).

A leitura sobre o âmbito político em Angola, a partir do personagem de Carmina, também traz reflexões importantes sobre o período e guarda uma proximidade com o personagem de Caposso, à medida que CCC não vê limites para o seu engrandecimento pessoal. O comportamento em relação aos seus empregados e ao seu marido também aponta para a persistência de uma cultura política autoritária nos anos após a independência. Retratado de diferentes maneiras, construído em variados níveis, o autoritarismo ainda se fazia presente no dia a dia da sociedade angolana. O relacionamento entre João Evangelista e Carmina em Desejo de Kianda é retratado de modo desigual; a paixão pela "energia" de CCC, que levou João ao casamento, não era recíproca: "E até hoje não se sabe o que Carmina encontrou nele" (Pepetela, 2008a, p. 4). Sua anomalia é descrita ao longo de todo o livro, enquanto que o avanço de Carmina sobre as propriedades do Estado para benefício pessoal demonstram a sua ascensão na carreira política, mas também desvelam a relação mercantil de seu casamento: "João ficou pensando em uma frase pronunciada por CCC que dizia que ninguém a comprava, só se fosse ao contrário (...). Até que ponto não tinha sido ele o alembado?" (Pepetela, 2008a, p. 8). Logo que se casou, Carmina se apropriou de um apartamento do Estado e o legalizou no nome de João. Adquiriu também um computador, dado de presente ao mari- 
do, através de uma "remessa comprada pela Jota e que depois foi distribuída entre os responsáveis” (Pepetela, 2008a, p. 31). Esses atos, que ocorrerão ao longo de todo o livro, bem como os destratos de Carmina em relação a João e às suas opiniões, colocarão Evangelista à sombra de CCC, aos poucos lhe conduzindo a um processo de desumanização. À medida que a guerra e a miséria em Angola avançam e Carmina encontra meios de se manter no poder, Evangelista se prende mais ainda em seus jogos no computador, abandonando o mundo para além do apartamento. Sem forças para lutar e também obtendo privilégios, o que no fundo considera errado, João Evangelista se esquece, em meio aos seus jogos de guerra, da triste realidade dos conflitos civis angolanos (Pepetela, 2008a, p. 31).

O retorno da guerra civil angolana em 1992 marca o tom narrativo presente em Desejo de Kianda. O romance é construído em meio à desilusão com a volta da guerra, que agora se aproxima da vida cotidiana da sociedade. A guerra que ocorre após o período eleitoral ganha novas proporções à medida que os confrontos são travados nas principais cidades do país, “o que se explica pela presença da Unita nas áreas urbanas durante todo o período pré-eleitoral" (Bittencourt, 2015, p. 246). São essas imagens de destruição que circularam em proporções mundiais e também estarão presentes na estória que Pepetela desenvolve no livro. Se, por um lado, Carmina é a representação de um Estado camaleônico que foi transfigurado à medida que os interesses econômicos e internacionais desejavam mudanças, por outro lado, o engrandecimento material do personagem dialoga com a presença crescente dos mutilados de guerra que, cada vez mais, se aglomeram nas ruas de Luanda.

Os dias foram passando com as notícias de outras cidades onde se combatia. Antes a guerra era apenas no campo, uma guerrilha que só aparecia próxima pelas consequências. Depois das eleições, a guerra passou a ser citadina, a destruir prédios. O governo tentava refazer o exército que se tinha dissolvido antes das eleições, recrutando maciçamente antigos militares e novos recrutas, comprando apressadamente o material que tinha sido desviado ou vendido ao desbarato (Pepetela, 2008a, p. 39).

O cenário de guerra é retratado, nas páginas do romance, praticamente junto ao desenrolar dos acontecimentos políticos em Angola, ao considerarmos a publicação do livro em 1995. Nesse sentido, são postas as dúvidas e os debates políticos do período, que apontavam também para as responsabilidades internacionais, condescendentes com o retorno da guerra, principalmente 
frente à "tolerância criminosa" da ONU (Organização das Nações Unidas) no que diz respeito à não desmilitarização da UNITA e ao fato de o MPLA se manter sozinho na direção do Estado durante o período das eleições. Messiant nos chama a atenção para o fato de o MPLA poder ter se utilizado dos recursos do próprio Estado para a sua eleição. Ou seja, "o MPLA pôde funcionar sem que as novas instituições democráticas fossem um problema e implicassem uma mudança nas suas relações com os cidadãos" (Messiant, 2006, p. 139).

Em Desejo de Kianda, se, no início, Carmina estava preocupada como o estouro da guerra e com os constantes bombardeamentos em plena capital, no transcorrer do conflito ela passa a encontrar meios de se beneficiar e entrar para o comércio de armas, com o seguinte argumento:

Como sabes, há o embargo internacional às duas partes em conflito. Quer dizer, o governo legitimamente eleito não pode legalmente se armar para se opor ao nosso inimigo que guardou ilegalmente todo o seu poderio militar. Mas há uma maneira de se resolver a questão. Certas empresas, que não são do governo, dão o nome para o governo comprar armas e munições a outras firmas de países que nem produzem armas. Claro que a empresa que dá o nome para a operação ganha uma pequena comissão, uma pequena percentagem porque é para um fim patriótico (Pepetela, 2008a, p. 39).

A guerra pós-eleitoral provocou uma série de problemas para a sociedade. Por mais que os dois lados tenham perpetrado uma guerra intensa, sem restrições quanto à crueldade das ações, a UNITA foi considerada internacionalmente a grande causadora da guerra. A derrota eleitoral reconhecida pela ONU não foi admitida e buscou ser desfeita a partir do uso da força ${ }^{10}$ Liderada por Jonas Savimbi, a UNITA passou a "ver a nova guerra como uma comprovação de sua capacidade bélica e da justeza de suas acusações ao governo angolano" (Bittencourt, 2015, p. 247). Podemos constatar, nesse momento, uma intensidade dos conflitos e um maior número de mutilados e deslocados de guerra, o que aparece em destaque nas páginas do romance do escritor angolano.

O constante pedido de esmolas dos meninos de rua esbarrava "nos últimos modelos de vidros fumados e ar condicionado, para proteger os passageiros desse tipo de importuno" (Pepetela, 2008a, p. 93). Do mesmo modo, os mutilados que agora "exigiam" alguma esmola também passavam a fazer parte do cenário urbano de Luanda, em meio aos prédios destroçados, aos sem-teto que perderam suas casas e não tinham mais para onde ir e ao caos que se instaurava na cidade. João Evangelista, em tempo, ao circular entre esses meios, 
cada vez mais se refugiava no seu computador e "se lançou ao jogo em desespero, esquecendo a vida” (Pepetela, 2008a, p. 98). O narrador de Desejo de Kianda retrata aquele momento como "um vento de loucura e morte [que] varria o território". A fome aumentava, a rede de esgoto não funcionava e os pedintes na rua não paravam de crescer. Ao mesmo tempo, "As pessoas importantes tinham carros de luxo, de vidros fumados, ninguém que lhes via a cara, passavam por nós e talvez nem olhassem para não se incomodarem com o feio espetáculo da miséria” (Pepetela, 2008a, p. 98).

O processo de desumanização da sociedade angolana permeia as páginas do livro, que, ao mesmo tempo, retrata a ascensão de um grupo elitista ao Estado angolano. Carmina Cara de $\mathrm{Cu}$ é uma representação desse núcleo, que se utiliza do Estado como um bem privado e transforma a política em instrumento para o seu enriquecimento. As transformações pessoais e políticas pelas quais passa Carmina estarão em diálogo com as mudanças que assistimos no interior do MPLA, afinal: "Carmina era sem dúvida uma filha do seu partido” (Pepetela, 2008a, p. 98).

Assim, após se converter à economia capitalista, Carmina abre uma empresa de import-export, a partir das vantagens que ser membro do Estado lhe possibilitou. O personagem passa a se comportar conforme determinava $\mathrm{o}$ novo figurino político. Assim, se torna empresária, ao mesmo tempo em que se elege como deputada pelo MPLA. As renovações políticas pelas quais atravessava Angola passavam a ser readaptadas a novos interesses, que continuavam beneficiando os mesmos indivíduos. O processo de democratização do regime permanecia longe, assim como a participação popular também não fazia parte da agenda política: "Se outros aproveitam da situação, porque não eu, ainda por cima por uma causa justa? Acabaram as morais do convento, agora estamos na economia de mercado. Existem três séculos de ética capitalista a demonstrar a legitimidade da coisa" (Pepetela, 2008a, p. 41).

Desse modo, o socialismo sempre aparece como um meio para se obter conquistas e vantagens. VC "nutria a fama de abnegado socialista, o que ajudava muito a considerá-lo pessoa íntegra, totalmente desinteressada dos bens materiais, um puro revolucionário em suma” (Pepetela, 2008b, p. 317). Quanto a Carmina, assim se descrevia: "Sou socialista, à merda as tradições obscurantistas" (Pepetela, 2008a, p. 7). Nos áureos tempos do socialismo como matriz ideológica do regime, Carmina era uma ferrenha militante, à frente do combate político às tradições religiosas, étnicas e regionais que pudessem impedir o avanço das concepções modernizadoras do socialismo. Segundo o nar- 
rador, o personagem era considerado "uma líder radical da Jota" (Pepetela, 2008a, p. 7).

Sabe-se que o socialismo não era um modelo político unânime dentro do MPLA. Apenas a partir do Congresso de 1977 afirmou-se a ideologia socialista do recém-criado Partido. O tradicional passa a ser caracterizado como obscuro e atrasado, frente ao modelo de construção do homem novo, enquanto que, em diálogo com um contexto internacional, o socialismo passa a ser a representação do moderno. Essa posição ressalta o quanto a propagação de um discurso como o socialismo tinha alcances variados entre a sociedade, que, por vezes, apenas se utilizava da retórica ideológica para obter benefícios e cargos políticos. Além disso, chama a atenção também como muitos intelectuais e políticos, após o fim do socialismo, afirmaram a falta de consistência político-ideológica entre os membros do partido e o uso indiscriminado dos conceitos e ideais socialistas (Bittencourt, 2010, p. 141).

\section{ENTRE A CRÍTICA E O SILÊNCIO}

A postura crítica de Pepetela a partir de seus romances dialoga com as críticas que virão das ciências sociais ao governo durante os anos em que o MPLA se perpetuou no poder. Ao longo das suas narrativas, a forma instrumental com que o Estado se autoproclamou socialista, assim como o alcance dessa teoria entre a sociedade, a partir de uma relação de interesses, complexifica o quadro político do contexto em que seus livros foram escritos.

O personagem de Caposso exemplifica essa realidade, principalmente a partir da sobreposição dos interesses individuais sobre os coletivos. Ao longo do romance de Pepetela, ele vai se modificando, encontrando oportunidades de enriquecer de acordo com as novas possibilidades que o modelo político lhe oferecia. Desse modo, se antes era bom manter sua fama de socialista, pois "tinha feito anteriormente constar que abandonara as pretensões a lojista por não concordar com o comércio privado, sendo um socialista de velha cepa, achando que o comércio só devia ser feito pelo Estado, coletivização total" (Pepetela, 2008b, p. 317), posteriormente, com a abertura do mercado econômico na década de 1990, os negócios passam a estar em primeiro plano. Pepetela ressalta em seu romance que, nesse momento, cada vez mais se "misturava cargos políticos com empresas meio clandestinas", o que vai ocorrer com Vladimir Caposso, que, assim como Carmina em Desejo de Kianda, passará a investir em comércio de armas. Em passagem relevante do livro, Caposso afirma: "Que se lixe a política, o partido e o marxismo! Quero é acumular fortuna 
e todos me respeitarão, pedirão favores, por muito marxistas que sejam" (Pepetela, 2008b, p. 339). Nos anos de 1990, VC larga a política e passa a ser somente empresário.

É interessante ressaltar que Caposso iniciou a sua carreira como empresário dentro das brechas do próprio regime político, ainda na fase socialista. Para Messiant, as relações de poder estabelecidas entre a sociedade e o Estado perpassam níveis de ilegalidade, corrupção e favoritismo, que, ao serem acordados, possibilitam um "afrouxamento da repressão" sobre as atividades ilegais, como, por exemplo, os candongueiros (Messiant, 2006, p. 136). É nessa via que Caposso adquire a sua frota de carros, inclusive, comprando-os no mercado internacional. À época, já era membro do partido e conseguia se beneficiar das vantagens de estar próximo do governo. Por outro lado, no momento seguinte, após a transição para o multipartidarismo e a abertura econômica do país, em que a adesão ao marxismo-leninismo não era mais obrigatória, $\mathrm{VC}$ deixa o partido e se lança em novos desafios do mercado internacional.

Em diálogo com o exemplo acima, Nuno Vidal afirma que, após a abertura econômica para o setor privado, "os processos de privatização que decorreram dos anos 1990 foram feitos a favor das elites no poder e hoje os mais lucrativos e politicamente cruciais ramos do setor privado assumem um caráter de oligopólio" (Vidal, 2006, p. 32). Essa lógica continuava a estar atrelada sobre uma política de interesses, denominada por Vidal como patrimonialista-clientelista.

No romance de Pepetela, à medida que o Estado vai se afastando das concepções políticas socialistas, as críticas aumentam, deixando evidentes as decepções com o governo: "Foram guerras épicas, essas do tempo colonial. E o MPLA veio e disse, cortem o arame, a terra é do povo. Gostei. Vinte e tal anos depois, começam a vir os mesmos para fechar os pastos e os caminhos com arame farpado" (Pepetela, 2008b, p. 185). Esta passagem se refere à fala de uma liderança social, Chipengula, que criou a DECTRA, uma associação pela Defesa dos Criadores Tradicionais. Segundo o personagem, esta ONG nasceu dos debates suscitados nos comícios do MPLA, nos tempos em que ainda "acreditavam em princípios (...) bons e inocentes tempos” (Pepetela, 2008b, p. 186). A participação política, o comprometimento com o partido e a ideologia socialista estão restritos aos interesses pessoais: enriquecimento e poder. O título do livro - Predadores - torna-se um importante instrumento técnico que associa a arte predatória à destruição da sociedade angolana. Capaz de tudo, esse grupo social emergente destrói todo o sonho de antes, assim como todos os ideais. 
Nesse momento é válido relembrar que Predadores é escrito em 2005, após o fim da guerra civil em 2002. Vivia-se um novo contexto político e social, com a promessa de eleições legislativas em 2008 e presidenciais em 2012. Contudo, o escritor angolano José Eduardo Agualusa chama a atenção para a "força e a revolta" de Pepetela ao escrever Predadores, o que, para ele, provavelmente, está em diálogo com o seu desencanto com a "forma com que evoluiu o regime angolano desde 1975” (AGUALUSA, 2008). Para Agualusa, Predadores encerra a escrita de desencantamento que marcou a produção de Pepetela. Em uma narrativa construída num vai e vem de tempos, o romance é uma obra fundamental para refletirmos sobre a sociedade angolana na contemporaneidade.

Ao apontar para os anos iniciais após a independência, Predadores reconstrói, a partir do distanciamento do tempo, as discussões em torno do âmbito político, que, mesmo após o fim da guerra civil, ainda parecia frágil e complexo. A luta pelo fortalecimento da nação, em torno de uma unidade que acreditasse no MPLA como o grande líder dessa nova nação, perdurava e não encontrava novas frentes de oposição que conseguissem travar o poder político que o partido ainda representava; por mais que as oposições de caráter civil cada vez mais se fizessem presentes. Por outro lado, os problemas internos enfrentados pelo Movimento, que desembocou em dissidências e rupturas, é, pela primeira vez, analisado nos romances de Pepetela. O silenciamento sobre o episódio que ainda aparece controverso na vida do autor - o movimento nitista - se rompe, mas sem aprofundamento: “Tão satisfeito andava que mal se apercebeu das lutas políticas ocorrendo no interior do movimento (...) até estoirar o 27 de maio de 1977, com um levantamento de militantes, mortes, e depois prisões em massa e execuções." (Pepetela, 2008b, p. 155).

Contudo, o nitismo aparece como um movimento também elitista em torno das disputas pelo poder político, reforçando uma memória sobre o movimento de que o 27 de maio teria sido obra de um grupo de "arrogantes ambiciosos" (Marques, 2012, p. 96). Dessa forma, os personagens mais bem quistos do romance, próximos a ideologias políticas democráticas e igualitárias, também são mantidos afastados do levante:

Chipengula e ele [Sebastião] se tornaram amigos na cadeia. Em 1976, quando se encontraram na prisão de São Paulo, acusados do mesmo crime, pertencerem a um comitê clandestino que considerava o governo demasiado de direita, desinteressado de fazer uma revolução socialista. 
Estavam na mesma cela quando se deu o levantamento do 27 de maio e se puseram à margem de tudo, era uma luta entre os detentores do poder, não lhes dizia respeito (Pepetela, 2008b, p. 182).

Ao nos voltarmos para essas passagens, é importante retomarmos o debate feito por Mabeko-Tali, que desenvolve o quanto o nitismo enquanto fenômeno político aponta para uma série de debates sociopolíticos existentes dentro do MPLA, debates que se tornaram mais evidentes quando da chegada do grupo ao poder. As frustrações sociais e as divisões ideológicas, encobertas, muitas vezes, pela luta em comum visando à libertação, passaram a ganhar opositores dentro do sistema político-partidário (Mabeko-Tali, 2001, p. 186). Todavia, esse debate é silenciado ao longo de toda a obra de Pepetela e, quando aparece em Predadores, mantém uma versão associada à direção do MPLA em 1977, logo após o golpe. Desse modo, as críticas que os nitistas fizeram à época, sobretudo relacionadas ao desvio político e à corrupção do Estado, não aparecem na obra de Pepetela. É interessante ainda ressaltar que as críticas desenvolvidas pelos nitistas, já vindas de outras dissidências internas, não serão colocadas na literatura de um dos escritores angolanos reconhecidos internacionalmente pela posição crítica ao governo e ao Estado angolanos no pós-independência.

A partir da reconstrução desse cenário, o escritor também retrata as disputas políticas que estavam presentes dentro do MPLA. O clima de tensão é narrado no romance, que faz referência às constantes desconfianças de todos, dando início às deposições de muitos membros do movimento. A mudança para partido também se fortalece nesse período, assim narrado por Pepetela:

Um dia apareceram umas teses longas e complicadas para os militantes discutirem e darem sugestões [...]. Textos compridos e chatos, no pensamento secreto de Caposso, realmente nem os leu. Mesmo o que dizia respeito à educação, sector onde actuava, não lhe mereceu a menor atenção. A discussão dessas teses no grupo foi rapidíssima, ninguém estava para se maçar nem tinha ideias. Foram todas aprovadas sem emendas, um modelo de perfeição (Pepetela, 2008b, p. 156).

O evento traz à tona as contradições existentes durante o movimento de Retificação após o movimento nitista. Através da ironia, Pepetela problematiza os desvios políticos presentes no MPLA. A entrada no atual partido tinha como critério a capacidade que o indivíduo teria para desenvolver o estudo e a divulgação do socialismo. Contudo, por outro lado, não havia a preocupação 
com o aprofundamento político e social do mesmo, o que favorece VC, que, mesmo sem ter interesse na política, forjava ser socialista - na época, um meio eficaz para se alavancar socialmente. Para Mabeko-Tali, a entrada para o partido no I Congresso de 1977, logo após o movimento nitista, buscava estabelecer critérios mais rígidos para a sua filiação, do mesmo modo, ressaltava "a exclusão de pessoas que tivessem apoiado, de qualquer forma, o colonialismo" (Mabeko-Tali, 2001, p. 231). Portanto, ao realçar as contradições existentes dentro do movimento, Pepetela acena para os desvios ideológicos e políticos que faziam parte das relações de poder internas do MPLA.

De acordo com Silvio de Carvalho, Pepetela participou desse processo de Retificação, assim como também aprovou a transformação do MPLA em Partido, por mais que não tivesse interesse em integrá-lo. Todavia, se, naquele momento, estava atrelado às posições da cúpula do partido, aos poucos dela se distancia e passa a criticar o modo como muitos militantes vivenciaram aquele movimento de modo superficial. Ao tratar desse tema em Predadores, propõe apontar para os interesses individuais de quem apenas se aproximava do partido para obter vantagens (Carvalho Filho, 2015, p. 128).

Ainda nesse contexto, conforme afirma Nuno Vidal, o processo de centralização e elitismo acaba se beneficiando da tentativa de golpe, pois agora o MPLA teria o argumento necessário para legitimar o autoritarismo praticado. Em nome da disciplina, o processo de centralização política foi sendo moldado ao longo dos anos, não permitindo nenhuma oposição até o ano de 1991 (Vidal, 2006, p. 14).

\section{Considerações Finais}

Assim, tanto Desejo de Kianda quanto Predadores abordam as relações de interesse que cercam a sociedade e o Estado. Carmina Cara de Cu e Vladimir Caposso são os representantes dessa burguesia emergente que corrompe e destrói as relações humanas. Não há limites para eles. A força com que se apropriam do Estado reflete o modelo político neopatrimonialista que a ciência política desenvolveu ao analisar os modelos políticos na África após o cenário de independências.

Notamos, a partir da construção dessas narrativas, o quanto, também ao longo do tempo, Pepetela vai buscando encontrar novas formas de participação política, menos atreladas ao modelo clássico do fazer política. Volta-se, nesse sentido, para a sociedade civil e para o alcance que as organizações cívicas podem ter no espaço político. Reflete as desilusões de um projeto político que 
não se concretizou como ele esperava, o que tem relação com a burocratização do político e com a emergência de homens descomprometidos com as causas sociais. Assim, tanto em um romance quanto no outro, a sua alternativa política é construída a partir de sujeitos que romperam com o MPLA, ou mesmo que nunca se aproximaram de qualquer outra frente partidária.

\section{REFERÊNCIAS}

AGUALUSA, José Eduardo. Orelha. In: PEPETELA. Predadores. Rio de Janeiro: Língua Geral, 2008.

ALUNOS DO PROGRAMA. Entrevista com Pepetela. Revista Crioula, São Paulo: FFLCH/USP, n. 13. 2013.

BITTENCOURT, Marcelo. Angola: tradição, modernidade e cultura política. In: REIS, Daniel Aarão; MATTOS, Hebe; OLIVEIRA, João Pacheco de; MORAES, Luís Edmundo de Souza; RIDENTI, Marcelo (Orgs.). Tradições e modernidades. Rio de Janeiro: Editora FGV, 2010. p. 129-144.

BITTENCOURT, Marcelo. Nacionalismo, Estado e guerra em Angola. In: FERRERAS, Norberto O. (Org.) A questão nacional e as tradições nacional-estatistas no Brasil, América Latina e África. Rio de Janeiro: FGV, 2015. p. 231-255.

CARVALHO FILHO, Sílvio de Almeida. Predadores: A escrita de si como subtexto da escrita do outro. REUNIÃO BRASILEIRA DE ANTROPOLOGIA, 28. 2012, São Paulo. p. 1-19.

CARVALHO FILHO, Sílvio de Almeida. Predadores: quando a literatura narra as relações de poder em Angola. Outros Tempos, v. 12, n. 19, p. 118-134, 2015.

CHABAL, Patrick. Prefácio Analítico. In: VIDAL, Nuno; ANDRADE, Justino Pinto de (Eds.). Sociedade Civil e Política em Angola. Enquadramento regional e internacional. 2a Edição. Lisboa: Edições Firmamento, Media XXI; Luanda: Adra Angola, 2009 [2008]. p. XIX-XXXIII.

CHARTIER, Roger. A história cultural: entre práticas e representações. Tradução de Maria Manuela Galhardo. Rio de Janeiro: Bertrand Brasil, 1990.

FONSECA, Maria Nazareth Soares. Literatura e "arquivos da memória”: negociação e dispersão de sentidos. In: SECCO, Carmen Tindó; SALGADO, Maria Teresa; JORGE, Sílvio Renato (Orgs.). África, escritas literárias. Rio de Janeiro: Editora da UFRJ; Luanda: UEA (União dos Escritores Angolanos), 2010. p. 77-84.

GINZBURG, Carlo. O fio e os rastros: verdadeiro, falso e fictício. Tradução de Rosa Freire D’Aguiar e Eduardo Brandão. São Paulo: Companhia das Letras, 2007.

MABEKO-TALI, Jean-Michel. Dissidências e poder de estado: o MPLA perante si próprio (1962-1977). Tradução de Manuel Ruas. V. 1. Luanda: Editorial Nzila, 2001. 
MARQUES, Inácio Luiz Guimarães. Memórias de um golpe: o 27 de maio de 1977 em Angola. Dissertação (Mestrado em História) - Programa de Pós-graduação em História, Universidade Federal Fluminense. Niterói, 2012. 132 p.

MESSIANT, Christine. Transição para o multipartidarismo sem transição para a democracia. In: VIDAL, Nuno; ANDRADE, Justino Pinto de. (Orgs). O processo de transição para o multipartidarismo em Angola. Lisboa: Edições Firmamento, 2006. p. 131-161.

OLIVEIRA, Ricardo Soares de. Magnífica e Miserável. Angola desde a Guerra Civil. Lisboa: Tinta da China, 2015.

PEPETELA. Desejo de Kianda. Lisboa: Dom Quixote, 2008a.

PEPETELA. Entrevista concedida à autora via correio eletrônico no dia 25 de julho de 2017. In: MACHADO, Carolina Bezerra. Relações de Poder em Angola: Uma leitura dos romances de Pepetela (1975-2005). Tese (Doutorado em História) - Instituto de História, Universidade Federal Fluminense. Niterói, 2019. p. 257-259.

PEPETELA. Predadores. Rio de Janeiro: Língua Geral, 2008b.

PESAVENTO, Sandra Jatahy. História \& literatura: uma velha-nova história. Nuevo Mundo, Mundos Nuevos: Débats, Paris: Mondes Américains, 2006.

PINTO, Marcelo Bittencourt Ivair. "Estamos Juntos". O MPLA e a luta anticolonial (1961-1974). Tese (Doutorado em História) - Programa de Pós-graduação em História, Universidade Federal Fluminense, Niterói, 2002. 742 p.

SANTOS, Daniel dos. A formação do Estado angolano na época da globalização. Antropolítica: Revista Contemporânea de Antropologia, Niterói: EdUFF, n. 1, 1995. VIDAL, Nuno. Multipartidarismo em Angola. In: VIDAL, Nuno; ANDRADE, Justino Pinto de. (Orgs). O processo de transição para o multipartidarismo em Angola. Lisboa: Edições Firmamento, 2006. p. 11-57.

VIDAL, Nuno de Fragoso. O MPLA e a governação: entre internacionalismo progressista marxista e pragmatismo liberal-nacionalista. Estudos Ibero-Americanos, Porto Alegre, v. 42, n. 3, p. 815-854, 2016.

\section{NOTAS}

${ }^{1}$ Entrevista realizada por alunos de Pós-Graduação do Programa de Estudos Comparados de Literaturas de Língua Portuguesa, do Departamento de Letras Clássicas e Vernáculas da Universidade de São Paulo, em novembro de 2010 (Alunos do Programa, 2013).

${ }^{2}$ Empresa estatal angolana do ramo petrolífero.

${ }^{3}$ Para Silvio Carvalho, essa posição de Pepetela não é fortuita, pois chama a atenção para esse novo riquismo, característico dessa classe que ascende socialmente em cima da pobreza alheia, contribuindo para o acirramento da desigualdade social no país (Carvalho Filho, 2015, p.133). 
${ }^{4}$ Caposso trabalhava em uma loja para um senhor português, Sô Amilcar. Quando do momento da independência, muitos portugueses deixam o país e Sô Amilcar é um desses que retornam para Portugal. Todavia, em tempo, pede para Caposso tomar conta da loja. Caso não voltasse, poderia ficar com tudo. A partir daí, os trâmites burocráticos para regularizar a loja em seu nome foram vários, mas sempre contaram com o apoio e as facilidades características do sistema burocrático administrativo do governo angolano.

${ }^{5}$ Polícia Internacional e de Defesa do Estado de Portugal, atuante na repressão durante o regime colonial.

${ }^{6}$ Pepetela se afasta amigavelmente do Estado em 1982. O escritor afirma que sua saída do governo se deveu ao seu desejo de se dedicar à escrita, o que realmente fez sua produção literária alavancar. Em nenhum momento afirma ter rompido de fato com o MPLA, ou mesmo ter se afastado por não caminharem mais juntos politicamente, embora, em seguida, os romances de crítica ao partido tenham ganhado destaque.

${ }^{7}$ União Nacional para Independência Total de Angola.

${ }^{8}$ A descrição de seus funcionários mais próximos assim é realizada: "José Matias era homem seu, fora buscá-lo à rua e ao desespero, ainda muito jovem, com medo de ir para a guerra, protegeu-o, livrou-o da tropa e lhe deu emprego, envolveu-o em negócios escuros, em perseguições e espionagens a rivais e concorrentes, em contratar gente para partir o braço a um devedor mais obstinado, não, José Matias nunca o trairia [...]. José Matias pertencia mais a Caposso que a Firmino Matias, seu pai”. Fátima "magricela”, sua secretária, assim é retratada: "fazendo todo o trabalho sem nenhuma reclamação, adorando horas extraordinárias, pronta para resolver problemas de casa dele nos fins de semana” (Pepetela, 2008b, p. 19 e 26).

9 “Tinha vergonha de contar aos pais que por vezes levava uma surra. Os velhos também não poderiam fazer grande coisa, se quisessem preservar o casamento da filha, coisa sagrada" (Pepetela, 2008b, p. 508).

${ }^{10}$ Devido ao resultado eleitoral em que Jonas Savimbi obteve 40,07\% dos votos e José Eduardo dos Santos 49,57\%, estava previsto, de acordo com a legislação eleitoral, um segundo turno. Todavia, Savimbi não reconheceu o resultado, alegando fraude, por mais que a ONU tenha considerado a eleição legítima. Por isso, a guerra foi retomada. Cf. Messiant, 2006, p. 139.

Artigo submetido em 6 de julho de 2020.

Aprovado em 6 de janeiro de 2021. 